\title{
Rrugëtimi i nxënësve të Normales së Elbasanit
}

\author{
Luljeta ISAKU
}

Pjesëmarrjen time në një aktivitet përkujtimor të 110-vjetorit të hapjes së Shkollës Normale në Elbasan, ku u shkollua edhe babai im, e konsiderova një respekt të veçantë.

Synimi kryesor i arsimit është arritja e zhvillimit etik, intelektual, fizik, social dhe estetik. Mësimi i mirëfilltë të integron në secilën shoqëri, të bën të mendosh në mënyrë të pavarur, të kesh vetëbesim, të dish të kritikosh dhe të bësh përzgjedhjen më të duhur në jetë.

Dija është investim themelor për të kuptuar gjërat e botës. Arsimimi dhe dituria janë baza kyçe për funksionim intelektual në jetë.

Premisa e Naum Veqilharxhit: "Më të mirën gjë që njohu e që kuptoi njeriu, ish të mësuarit”, lëshoi shtat që herët në mesin e popullit shqiptar. Për të arritur qëllimin kryesor, ngritjen dhe ndërgjegjen kombëtare rilindasit, kudo që jetonin, u munduan të përhapnin kulturën dhe dijen në gjuhën e kombit.

Mendime, ide dhe qëndrime iluministe e përshkojnë epokën e Rilindjes Kombëtare Shqiptare, si në rrafshin e historisë ashtu edhe në atë të kulturës.

Nevoja e madhe që diktonte çasti historik, ngarkesat dhe detyrat e shumta lidheshin me nevojën e ngritjes në masë të ndërgjegjes kombëtare, e cila duhej të bëhej në një institucion, siç ishte shkolla. Themelimi dhe përhapja e arsimit në gjuhën amtare do të viheshin në shërbim të ngritjes e të edukimit të ndjenjës kombëtare, si dhe në atë të luftës kundër paragjykimeve, që kishin qenë pengesë serioze e përparimit shoqëror, politik, ekonomik dhe kulturor.

Epokën e Rilindjes Kombëtare Shqiptare e karakterizon, në rrafshin politik, lëvizja e ndërgjegjshme dhe e organizuar e luftës për çlirim kombëtar, ndërsa në rrafshin kulturor, zhvillimi i mendimit politik shoqëror, me tipare të qarta iluministe. 


\section{Albanon}

\section{Revistë kulturore}

Çështja e alfabetit dhe shkollës kombëtare, bëhet preokupimi vendimtar i rilindasve, sepse kjo synonte ndryshimin e ndërgjegjes njerëzore të kohës, atë të mënyrës së të menduarit dhe të qëndrimit të njeriut ndaj gjendjes së përgjithshme shoqërore, ekonomike dhe politike.

Të gjithë shqiptarët që morën penën në dorë karakterizoheshin nga një vetëdije e lartë dhe e veçantë për kohën dhe detyrën e tyre historike.

Dita e hapjes së Shkollës Normale të Elbasanit, është një ditë me rëndësi në kalendarin e së kaluarës dhe një faqe e ndritur e arsimit dhe kulturës sonë.

Për herë të parë më 1 dhjetor të 1909, 140 nxënës nga e gjithë Shqipëria, gjysma e tyre nga Çamëria e Kosova, u ulën në bankat e shkollës së parë të mesme në Shqipëri, Normales së Elbasanit. Si vatër e përgatitjes së mësuesve shqiptarë në gjuhën shqipe, ajo e kreu në mënyrë të përsosur misionin e saj historik, duke përgatitur mësues të devotshëm, profesionistë të spikatur dhe patriotë të vërtetë.

Gjatë peridhës 1941-1948, një numër i mësuesve të kësaj shkolle elitare, shërbyen në trojet shqiptare jashtë territorit të Shqipërisë, në Kosovë, Maqedoni e Çamëri. Ajo hapi horizontin e dijes, në një kohë kur analfabetizmi bënte shumë hije te shqiptarët. Përmes vështirësive të shumta, bëri hapat e parë të sigurtë dhe shpresëdhënës për një rrugëtim intelektual të shqiptarëve dhe edukim të mirëfilltë në frymë kombëtare. Shkolla përgatiti jo vetëm njerëz me një bagazh të caktuar njohurish në fusha të ndryshme, por edhe qytetarë aktivë të shoqërisë. Hapja e Shkollës Normale në Elbasan dhe angazhimi permanent i intelektualëve shqiptarë, i parapriu pavarësisë së Shqipërisë.

Normalistët e Elbasanit reflektuan dukshëm edhe te shqiptarët e Maqedonisë Në pranverën e vitit 1941, shqiptarët e Tetovës për herë të parë morën të drejtën e qeverisjes komunale. Kjo shënoi një kthesë historike edhe në arsimin shqip, jo vetëm në Tetovë po edhe në qytete të tjera. Një numër tetovarësh, me kapacitet të lartë intelektual, u aktivizuan për ta ndihmuar këtë bashki.

Nga Shqipëria erdhën kuadro të sektorëve të ndryshëm, për të formuar institucionet e bashkisë. Nga ky kuadër, rruga e vetme e ngritjes kombëtare, shihej përmes shkollës, librit dhe dijes.

Kësaj kauze ju bashkangjitën edhe disa patriotë tetovarë. Duhet veçuar veprimtaria patriotike e intelektuale e Selim Shehapi-Luma, deputet i zonës në Parlamentin e Shqipërisë. Me qëllim të përhapjes së librit shqip, 
të shkrimit dhe të leximit në gjuhën amtare, Selim Shehapi-Luma, solli ilegalisht nga Shqipëria abetaren e parë në gjuhën shqipe dhe disa tekste të tjera, për nxënës fillestarë. Ardhjen e këtyre librave e ndihmoi edhe konsullata e Shqipërisë në Shkup.

Mungesa e mësuesve ishte e madhe. Vetëm tre shqiptar në tërë territorin e Maqedonisë ishin mësues, Azem Morana nga Shkupi, Idriz Idrizi nga fshati Gajre i Tetovës dhe Mithat Cami nga Dibra, të cilët në gjuhën serbishte u jepnin mësim nxënësve shqiptarë.

Meqenëse nevoja për hapjen e shkollave në gjuhën shqipe ishte e madhe, deputeti Selim Shehapi-Luma udhëtoi për në Tiranë, për t'u takuar me Mehdi bej Frashërin, me të cilin njiheshim që më herët. Nëpërmjet tij caktoi takim me Ministrin e Arsimit, Ernest Koliqin. Në këtë takim kishte kërkuar që në Tetovë të hapeshin shkolla me mësim në gjuhën shqipe dhe jo vetëm në qytet, por edhe në fshatra. Kërkesa e dytë drejtuar ministrit të Arsimit të Shqipërisë ka qenë që të dërgoheshin arsimtarë të kualifikuar për mësues. Ministri Koliqi kishte mbështetur këtë kërkesë, prandaj në Tetovë, Gostivar, Dibër dhe Strugë, Ministria e Arsimit e Shqipërisë emëron një numër mësuesish me përvojë, normalistë të Elbasanit, që të angazhoheshin në mësimdhënie në gjuhën shqipe. $U$ angazhuan 50 mësues, 30 nëpër fshatra dhe 20 në qytet. $U$ formuan 22 paralele në klasat e fillores, në të cilat mësonin 1000 nxënës.

Mësuesit e parë të ardhur nga Shqipëria në Tetovë, kryesisht kanë qenë nga Elbasani. Në mesin e tyre ishin: Rustem Ismailati, Hysen Hoxha, Josif Todi, Fatbardha Caushi, Kadri Hoxha, Abedin Faja, Vasil Dhimitru, Xhafer Narazani. Në fshatra, Murteza Peza, Dhimitër Shuli, Murtezan Kazadei.

Me 1 shtator 1941 filloi viti i parë shkollor, në një objekt të ndërtuar shumë kohë para Luftës së Dytë Botërore. Shkolla u pagëzua me emrin "Skënderbeu" (që pas Luftës së Dytë Botërore u quajt "Marshall Tito", e tani "Goce Dellcev", hero i kontestuar nga Bullgaria, për prejardhjen e tij.)

Për këtë fillimviti paraprakisht u organizuan disa kurse speciale në të cilat i kushtohej rëndësi gjuhës amtare. Enkas, për këto kurse ishin caktuar mësuesit Mithat Cami nga Dibra dhe Vasil Dhimitru nga Elbasani.

Objekti i shkollës "Skënderbeu" nuk kishte kapacitet hapësinor për të vendosur nxënësit e regjistruar. Për arsye të interesimit shumë të madh, procesi i mësimit u zhvillua edhe në disa objekte ndihmëse, të cilat nuk plotësonin kriteret institucionale. Në objektin kryesor, në shkollën "Skënderbeu", drejtor u emërua mësuesi Beqir Kllojka nga Peqini, ndërsa në shkollën “Tajar 


\section{Albanon}

\section{Revistë kulturore}

Tetova” (objekt ndihmës) mësuesi elbasanas Qemal Haxhihasani. Inspektor i arsimit për këto shkolla ishte emëruar Mexhait Bekteshi nga Kavaja.

Sipas dëshmive të tetovarëve, mësues të moshuar, Spiro Popa ka qenë mësuesi i parë në Shkollën "Skënderbeu". Pas tij vijnë edhe një numër i madh mësuesish të tjerë. Pas hapjes së shkollës arrijnë edhe abetaret në gjuhën shqipe. Sigurohen revista, 10 mijë ekzemplarë librash të ndryshëm dhe një libër me këngë popullore. Këto libra, paraprakisht grumbulloheshin në shtëpitë e tetovarëve. Futjen e librave shqip në këto treva, e ka ndihmuar Konsullata e Shqipërisë në Shkup dhe Teqeja bektashiane në Tetovë, e quajtur "Harabati Baba Teqe".

Në këto vite në krye të kësaj teqeje ka qene i emëruar Baba Qazimi (Qazim Bakalli) nga Elbasani. Kjo teqe ndihmoi shumë nxënës, që vinin nga fshatrat e Tetovës në shkollën "Skënderbeu. Në vitet 1942-1945 me buxhetin e saj, në Normalen e Elbasanit, shkolloi shkrimtarin nga Tetova, Murat Isaku.

Një numër mësuesish të ardhur nga Shqipëria, kanë punuar edhe në shkollat e fshatrave, Rrustem Ismailati, Hysen Hoxha, Josif Todi, Fatbardha Caushi, Kadri Hoxha, Abedin Faja, Vasil Dhimitru, Xhafer Narazani etj.

Më 1944, Ministria e Arsimit të Shqipërisë, emëroi mësuesin Jonuz Balla nga Elbasani, drejtor të shkollës "Skënderbeu” në Tetovë. Shumë shpejt kjo shkollë u shndërrua në vatër të madhe arsimi. Nxënësit e parë të saj u bënë nxënës të shkollës "Haxhi Tasini” në Tetovë, e cila u hap si "gjimnaz i ulët”. Në këtë gjimnaz ka pasur 5 paralele, me gjithsej 165 nxënës. Profesor të kësaj shkolle "gjysmë të mesme", kanë qenë Zeqirja Spahiu nga Tirana dhe Vasil Naqi nga Elbasani. (“Distinkti tetovar”, Ismail Asllani, 2008 Tetovë. )

Më 1 shtator 1945, nëpër shkollat e Tetovës dhe rrethinës u angazhuan mbi 100 mësues, ish-nxënës të diplomuar në këto shkolla. Ata ishin kuadrot e para shqiptare vendase, që bartën peshën e arsimit për brezat që vinin.

Kontibuti i mësuesve shqiptar nga Shqipëria gjatë viteve të punës së tyre në Tetovë, nuk u fokusua vetëm në mësimdhënie. Aktivitetet e tjera në sferën e kulturës, reflektuan dukshëm në emancipimin e shqiptarëve të kësaj ane.

Më 1941, mësuesit nga Normalja e Elbasanit formojnë organizatën ilegale kombëtare "Besa". Me iniciativën e saj hapet Shtëpia e Rinisë, si dhe themelohet grupi i dramës dhe orkestrina e mandolinave.

Drama e parë e përgatitur nga ky grup, titullohej "Të burgosurit". Autor dhe regjisor i saj ishte mësuesi nga Shqipëria, Hamit Shijaku. Rolet në dramë u luajtën nga mësues e nxënës të shkollës "Skënderbeu”. 
Pas tri viteve, kryesia e organizatës "Besa" do të angazhojë mësuesin nga Elbasani Qemal Haxhihasanin, të përgatisë dramën "Lulja e kujtimit" të Foqion Postolit. Premiera e dramës ishte dhënë simbolikisht më 28 Nëntor 1943, në Shtëpinë e Rinisë në Tetovë.

Po në vitin 1943, organizata "Besa" formoi një orkestër me instrumente frymore. Udhëheqës dhe dirigjent i orkestrinës së mandolinave, u caktua mësuesi nga Elbasani Gani Jaja, i cili një kohë kishte qenë i angazhuar në orkestrinën e mbretit Viktorio Emanuell III në Romë.

Në Tiranë u blenë 20 lloje të instrumenteve frymore. Brenda tre muajve orkestrina u aftësua për ekzekutimin e kompozimeve të ndryshme frymore. (“Distinkti tetovar", Ismail Asllani, 2008 Tetovë.)

Në kuadër të organizatës "Besa”, themelohet biblioteka e parë shqipe me emrin "Skënderbeu”, ku nëpunës emërohet mësuesi Setki Kiciki, nga Elbasani.

Në periudhën 1944-1945, një numër i madh i mësuesve u kthyen në Shqipëri. Në Tetovë kishin mbetur 10 mësues: Jonuz Balla, Veronika Lora, Ana Sopi, Zija Sadiku, Elena Pulati, etj.

Mësuesi Jonuz Balla nga Elbasani, më 1945 emërohet inspektor i arsimit në Bashkinë e Tetovës. Ai luajti rol të rëndësishëm për arsimin shqip në territorin e Maqedonisë. Angazhimi i tij lidhet më së shumti me kontributin që dha për hapjen e kurseve pedagogjike. Këto kurse u themeluan enkas për shqiptarët pa dallim moshe, që dinin shkrim e lexim në gjuhën shqipe. Kualifikimi i tyre kishte rangun e të diplomuarit në shkollë Normale.

Emrat e mësuesve Jonuz Balla, Qemal Haxhihasani, Gani Jahja e të tjerë, me nostalgji janë kujtuar gjeneratë pas gjenerate nga tetovarët. Sot kanë mbetë vetëm në kujtesën e më të moshuarve. Asnjë institucion nuk mban emrin e tyre. Iniciativat e intelektualëve lidhur me këtë, gjithmonë kanë dështuar nga politika ditore.

Këta mësues barazoheshin me një misionar dhe mësimdhënia konsiderohej vokacion. Misionari nuk kursehet, nuk ka orar pune dhe nuk synon shpërblime.

Sipas liderit socialist francez Jean Jaures: "Nuk mund t’u mësosh të tjerëve atë $q \ddot{e}$ di, nuk mund t’u mësosh as atë që do dhe as atë që pretendon se di; mund t'u mësosh veç atë që ti je.".

Shpesh parashtroj pyetjen: Të qenit mësues në atë kohë, po edhe në këtë kohë, është mision apo profesion? 